\title{
ROADS KILLS OF MIGRATING GARTER SNAKES AT THE PAS, MANITOBA
}

WALTER KRIVDA, Box 864, The Pas, Manitoba. R9A 1 K8

On 1 September 1991, a special trip was made to the Landry Lake area to collect plant specimens and to look for Fairy Bells (Disporum trachycarpum). A single colony of some eight plants was found $4 \mathrm{mi}$. west of Landry Lake, on the gravel road to Moose Lake, about $62 \mathrm{mi}$. northeast of The Pas. Another colony of somewhat more robust plants was found near Frog Creek. These are slight range extensions locally. As a spin-off from the botanical trip some observations were made on the dead and dying snakes found on the highway. These observations are recorded here.

In the course of travelling between Frog Creek and Landry Lake, I counted 32 dead garter snakes on $20 \mathrm{mi}$. of gravel road. In the remaining $10 \mathrm{mi}$. from the railway track where Highway 287 and the Moose Lake Road meet, another 10 garter snakes were found on the road to The Pas, near the airport. A total of 42 crushed, dead snakes were counted in this stretch of 30 miles.

The area near the airport has long been known as a garter snake winter denning area. The limestone dens have never been found, but were reportedly known to the late Fred Kowalchuk, who ran a summer store on the beach area for many years. The area between Landry Lake and Frog Creek, on the Moose Lake
Road, is reported here for the first time as a likely winter snake denning area.

The dead snakes were on the small side, perhaps averaging 18 inches. Only two were juveniles one very thin and $14 \mathrm{in}$. long, and the other only as thick as a pencil and perhaps a foot long.

Two of the less damaged, roadkilled snakes were repeatedly washed in rain water until blood ceased to appear in the wash water. This removed all the grit and gravel from the wounds. The two specimens have been liquid preserved and added to my collection. The label contains the following data: "Taken between Landry Lake and Frog Creek, near The Pas, Manitoba. September 1st, 1991. Collector: Walter Kridva, George Cook."

As an afterthought, the smallest snake seen, which was only as thick as a pencil, has also been added to the aforementioned jar of liquid preservative.

Local road kills of garter snakes by the airport, in particular, have been going on for over 50 years now. In this time vast numbers of snakes have been killed by the passing traffic. The major area is only about two miles long on Highway 287 near the airport. 
Signs should be put up, alerting drivers. The traffic should be slowed in this stretch of road, as this would likely decrease the carnage, both spring and autumn.

The place could be made a tourist attraction, instead of one where snakes are relentlessly slaughtered. The garter snake is the only snake species we have this far north in the province.

Everyone interested in snake conservation at this site should write: The Mayor of The Pas, the Mayor's
Office, Town Hall, The Pas, Manitoba. R9A $1 \mathrm{~K} 8$

In the early 1960 s some 3,000 to 5,000 snakes were collected yearly by the airport for a local export company. This was halted by the government of the day on the protestations of the Manitoba Naturalists' Society. The snakes were sold at 35 cents each, mostly to American universities, where they were used in zoology classes in medical schools to illustrate an intricate nervous system. I have this information from a local snake exporter.

\section{ERRATA}

In the June 1993 Blue Jay (51: 127), E. Otto Hohn wrote a letter about how squirrels carry their young, which had errors in the reference to a book. The correct reference is $T$. Bouliere. 1960. Natural History of mammals, 2nd Edition. Alfred Knopf, New York. P. 178.

It was not long, however, before the grasses of England appeared in the Colonies. On shipboard the animals were fed the forage provided them, and when they were landed the ships were cleared of litter and manure. The grasses thus introduced spread rapidly and in a few generations came to be regarded as indigenous. E.E. Edwards, 1948. Grass: the Yearbook of Agriculture. Washington. 